\title{
Dewey's Naturalistic Metaphysics: Expostulations and Replies
}

\author{
Randy L. Friedman
}

\begin{abstract}
Critics of Dewey's metaphysics point to his dismissal of any philosophy which locates ideals in a realm beyond experience. However, Dewey's sustained critique of dualistic philosophies is but a first step in his reconstruction and recovery of the function of the metaphysical. Detaching the discussion of values from inquiry, whether scientific, philosophical, or educational, produces the same end as relegating values to a transcendent realm that is beyond ordinary human discourse. Dewey's naturalistic metaphysics supports his progressive educational philosophy. The duty of education is grounded in its service to democracy; it must help students develop the ability to express, discuss, and develop their moral reasoning through experiential and experimental learning.
\end{abstract}

There may be two or three truths in professional philosophy, even for those who work in American pragmatism: Old debates never die, and new debates are often restatements of old debates. And the same technical term or concept means different things to different people-sometimes even to the same person. The debate over the terms of pragmatism is especially prevalent in Dewey studies, where battle lines have been drawn between those who read Dewey as a naturalist who eschews even the slightest hint of the metaphysical, and those who find in Dewey a pragmatist whose naturalism is complemented by a reconstructed metaphysics, which is a necessary component of his instrumental philosophy. Melvin Rogers (2009a) correctly points out the "industry of commentary on this formulation of Dewey's that makes him the problem, rather than framing investigations into Dewey from the perspective of the problem he seeks to address" (100). Writing in the pages of Education and Culture, Gert J. J. Biesta has challenged scholars of Dewey to incor- 
porate the purpose of his pragmatism into the study of his philosophical method: “As long as we approach Dewey's philosophy just as a philosophy, that is, as long as we engage with his work at the level of his beliefs rather than in function of the wider problem he sought to address, we severely restrict the opportunities that his pragmatism has to offer for dealing with the problems that characterize our global condition at the dawn of the twenty-first century: problems that have to do with intercultural, interethnic, and, not in the least, interreligious communication and understanding" (35). It is very much in this spirit that I will both criticize those philosophers who deny that Dewey offers a metaphysics and explain the value and significance of his naturalistic metaphysics in terms of his philosophy of education.

When we read Dewey's metaphysics as a corrective to traditional metaphysics and materialism, its central role in his overall philosophy becomes clear. At stake is a more helpful reading of Dewey which focuses on the specific methods and goals of his philosophical approach - an approach which in many ways reflects the melioristic and democratic goals of his work. The problems Dewey addresses play out most forcefully in his work on education, where some educational methodologies are shown to share a great deal with traditional metaphysics. Dewey's dismissal of distant, fixed, and permanent moral truths finds expression in his critique of certain methods of moral education; neither is able to generate the type of moral training or reasoning which is crucial to the success of the democratic culture Dewey celebrates and nurtures. To make my case, I will revisit his exchanges with one of the first critics of his metaphysics, George Santayana, and review the recent debate in the work of Richard Rorty, Charlene Haddock Seigfried, William T. Myers, John R. Shook, and others. Finally, I will offer a functionalist definition of Dewey's naturalistic metaphysics, and examine its application in some of his central work in education.

Those who reject the idea that Dewey offers a metaphysics argue that he turns away from the transcendental, supernatural, or absolute, toward a progressive understanding of culture, duty, and education which does not look to anything beyond, or more than the data of simple experience. This version of Dewey masks or ignores the larger task he sets for philosophy as a critical voice in democratic culture. The public role of philosophy, according to Dewey, is predicated on the recognition that ideals are encountered, as well as generated, through experience, and not endowed by a divine power or imparted by tradition. Some recent pragmatists, most notably Richard Rorty, embrace Dewey based on a reading which has him rejecting the constructive role of philosophy in public discourse as well as metaphysics tout court. Their objections, as we will see, are to another mode of metaphysical speculation which seems to have a monopoly in the field, which posits the very essences Dewey spent his career dismissing as anathema to his instrumentalist philosophy. Many who disagree with the picture of Dewey which Rorty sketches-as a philosopher moving beyond philosophy-agree with him that Dewey does not offer a reconstructed metaphysics.

I part company with both critiques, arguing instead that Dewey emphasizes his criticism of metaphysics not for the purposes of dismantling it, but in order to 
reconstruct and to put it to use in his pragmatism. In fact, Dewey explicitly claims that his instrumentalism depends on a metaphysics which he defines as forward looking, plastic, and concerned with the betterment of society. In this sense, metaphysics modifies naturalism by offering an examination both of the general characteristics of nature as experienced, and the values and function of these experiences in society as it seeks to improve itself. This understanding of naturalistic metaphysics is missed in the current debate.

The central thesis of this paper is that Dewey reconstructs, but does not abandon metaphysics. To do this, he recognizes a socially constructed ideal realm which is generated from and supports experience. Unlike traditional philosophical metaphysics, the ideal in Dewey is neither fixed nor absolute. Just as Dewey rejects any dualism which divides the ideal from the real, his reconstructed metaphysics does not posit an essential and timeless realm above experience. Rather, the two are mutual and complementary. There is no hard divide between nature or experience, "what is causally efficacious," and values or ideals (Detar, 28). My reading of Dewey's metaphysics differs from others which might be sympathetic. Richard Bernstein supports the "naturalistic metaphysics" line of interpretation. He describes metaphysics as "the study of the generic traits of existence; it is descriptive, empirical, and hypothetical" (5). This second standard definition of metaphysics-which is meant to compete with the supernatural or ideal version-does not sufficiently express the moral function of metaphysics Dewey recovers.

One of the primary goals of Dewey's pragmatism was to animate the moral life of nature and culture. He does this expressly in his educational philosophy, where the consequences of certain metaphysical assumptions play out with great force. In an autobiographical essay published in 1930, "From Absolutism to Experimentalism," Dewey derides the "intellectual scandal" of the division between science and morals. The creation of "a method of effective inquiry, which would apply without abrupt breach of continuity to the fields designated by both of these words, is at once our needed theoretical solvent and the supply of our greatest practical want." Dewey describes this cause as the central motivation for his instrumentalism ([1930] 1984c, 156-57). Dewey often defines his instrumentalism in terms of its application in education and philosophy of education. The methods of both require "draw[ing] . .. original material as to ends and value from actual experience in education, but ... goes back to these experiences for testing, confirmation, modification, and the provision of further materials" ([1929] 1984b, 30). The primary significance of Dewey's naturalistic metaphysics for philosophers of education is found in his claim that values can be and are taught through experience and experimentalism. In other words, moral character is not developed adequately when ideals are situated beyond experience, understood as fixed principles, and accessed through rote learning.

Scholars of education appreciate that pragmatism might be naturalistic, support a concept of the self as socially embodied, and advocate toleration and the pluralistic respect for certain ideals which reflect all of the above. Nel Noddings 
connects the approach to education in Dewey with his overall goals: "For Dewey, ways and means and ends and outcomes form a whole. We cannot use dictatorial means to educate democratic citizens." Democratic citizenship "entails powers of self-direction, administration, and responsibility. Training in mere obedience is insufficient" (481). Susan Jean Mayer notes that democracy is a moral ideal for Dewey (50), and that his appreciation of "the social nature of humankind" (52) is deeply connected with his rejection of instruction which does not demand critique and experiment. The best teacher does not present knowledge as fait accompli, but rather motivates, inspires, and guides (57). Again, the sustained criticisms of absolutism, and the advocacy for instrumentalism and pluralism in Dewey's philosophical works, find their practical expression in his philosophy of education.

\section{Lines of Interpretation}

In addition to clarifying Dewey's use of terminology, I will need to answer the question of what is gained by emphasizing Dewey's reconstructed metaphysics. To do this, of course, I will make the case that a great deal is lost by interpreters who claim that Dewey dismisses all metaphysics. My reading of Dewey throws into question the persistent interpretation, best exemplified by Richard Rorty, which has Dewey leaving behind not just metaphysics, but philosophy, too. For Rorty, the motivations for abandoning metaphysics (refusal to celebrate essences, a priori truths, ideal and transcendent realms of existents, etc.) should lead one to move beyond philosophy. This is decidedly not the case with Dewey. A brief note on perhaps the most widely known interpreter of Dewey is necessary.

Rorty dismisses any possibility that Dewey's work produces a metaphysics, in line with his assertions that Dewey does not practice philosophy in any traditional sense. Still, Rorty identifies two Deweys: one who refuses to abandon the vocabulary of traditional metaphysics, and another who shares with Rorty a sense of philosophical irony. Rorty-and his preferred Dewey—have moved beyond philosophy's traditional epistemological engagements with questions of truth and reality. This rendition of pragmatism does not fit the engaged, public, and active philosophy I find Dewey proposing. Rorty's liberalism does not fit Dewey's, either. As Richard Shusterman writes, "long-term friends and pragmatist fellow travelers like Richard Bernstein are dismayed at how Dewey's radical and clearly anticapitalist liberalism is being distorted" by Rorty (Shusterman, 391-92). Shusterman is less interested in grading "Rorty's fidelity" to Dewey, and more in tracing the "philosophical roots" of their divergences (392). In line with this goal, Shusterman writes that Rorty "rejects what he sees as Dewey's privileging of natural science over literary culture, just as he refuses to countenance philosophical discourse that traffics, as Dewey's does, with nonlinguistic entities like experiences or ideas" (391). While I will try to avoid offering the kind of exercise in "historical purism" Shusterman dislikes, I will make the case that things like ideas are central in Dewey's metaphysics, and that dismissing these central tools in his work strips Dewey's philosophy both of 
its goals and the means of achieving them. Shusterman understands "Dewey's attack on the metaphysics of traditional liberalism" to be a defense of the "collaborative effort to achieve greater frequency and security for these desired ends in a changing and contingent world whose future can in some measure be influenced and improved by human action and experimental intelligence." Dewey opts for a demanding meliorism in place of an almost quietest metaphysics which holds that "individual liberty rest [s] on ontological and inalienable givens of human nature" (Shusterman, 393-94).

Dewey's rejection of this second type of metaphysics does not imply that he rejects metaphysics outright. This may be the point of departure for Dewey and Rorty's respective liberalisms; Dewey imagines a "central" role for philosophy in "sociopolitical reform, not by deducing ontological foundations for such reform, but by imagining the best ends and means for it" (Shusterman, 403). Rorty can neither imagine any use for metaphysics, nor any useful public philosophy. Gregory Pappas points out that "if the only way philosophy can provide justification for our democratic aspirations is in the form of a knowledge foundation or from some historical objective standpoint, then Dewey has failed as a defender of democracy. Such failure is assumed by Richard Rorty, who believes that a pragmatist must abandon, once and for all, the notion that she can provide a philosophical justification for democracy or any other way of life" (Pappas, 260-62). David L. Hildebrand's assessment of Rorty on Dewey is particularly helpful in showing both the purpose of Dewey's metaphysics, and its grounding in naturalism. In short, he writes "Rorty is convinced that attempts to systematically describe the world in general terms are either banal statements of the obvious or the thinly disguised religious dogma of self-appointed priests. But Dewey showed another alternative was possible: metaphysics could investigate the world empirically and hypothetically" (116). Dewey's metaphysics modifies naturalism, and ensures that it does not become positivistic and reductively materialist; reconstructing metaphysics also revives empiricism-it allows Dewey to put experience to use in ways Rorty disavows.

Without doubt, Dewey does not present his metaphysics as an "attempt to find an independent Being on which mere encountered Nature depends" (Randall, 404). Dewey (and John Herman Randall) reclaim metaphysics as a mode of critique and inquiry whose focus is "productive" and not "purely theoretical" (Boisvert 1988, 104). But the metaphysics which Dewey reconstructs, while analyzing the "generic traits of existence," does not easily fit the model Randall identifies as the Aristotelian model. ${ }^{1}$ James Gouinlock notes that Dewey's metaphysics is natural and not Idealist, and that "what is emphasized with unrelieved urgency is that any and every mode of experience is evidential of the traits of nature. Not only knowing, but valuing, loving, worshipping, desiring, and dreaming also go on in nature; and the metaphysical inquiry concerns what are the irreducible traits of that nature in which such diversity of events occur" (6). The goal is neither simply explanatory nor "mere intellectual entertainment," but "to discern, describe, and explain the 
function of the pervasive characteristics of experience" $(9,39)$. Again, critics of Dewey's metaphysics overlook its purpose and function, especially its application in his philosophy of education.

The debate over Dewey's metaphysics begins in his own exchanges with Santayana, and extends immediately after Dewey's death through successive generations of interpreters. R. W. Sleeper (1960) defends Dewey against Morton White and George Geiger, who accept Dewey's philosophical methodological innovations stripped of the "metaphysical perspective which accompanies them" (101). Sleeper makes the point that "not all naturalism is anti-metaphysical," adding the helpful definition from John Herman Randall, Jr. that "the function of metaphysics is critical," and that metaphysics is "the ground-map of the province of criticism" (102). ${ }^{2}$ Gouinlock concurs in much the same language:

A naturalistic metaphysics provides a "ground-map" of criticism in the obvious sense that it makes clear the continuities and intermixtures of the traits of nature and it displays their function in various kinds of experience. Thus it makes criticism of values both intelligible and efficacious. If only implicitly, any coherent and effective theory of criticism must presuppose a metaphysics that characterizes nature at least as thoroughly and faithfully as that of Dewey. (41)

Dewey's metaphysics may be short-sighted; and perhaps it is naive in its regard of science's implicit reductionism. But Dewey is undoubtedly working on a metaphysics which fits with and serves his naturalism.

Revisiting Dewey's response to Santayana allows me to make the case as strongly as possible that Dewey intentionally and explicitly embraces a reconstructed metaphysics which he believes brings out aspects of nature ignored by both science and traditional metaphysics.

\section{Dewey and Santayana}

Well before Rorty, Seigfried, Myers, Shook, and others examined the characteristic elements of a pragmatist metaphysics, John Dewey and George Santayana debated the same basic set of questions. Many of the terms Santayana and Dewey use are identical, though most of the meanings are significantly different. For our purposes, Santayana's charge against Dewey parallels the current line that pragmatism (and naturalism) cannot be metaphysical, and that metaphysics precludes naturalism.

Santayana (1925) published one of the first critiques of Dewey's Experience and Nature, often read as the central statement of Dewey's metaphysics. He opens his essay with the question most readers of Experience and Nature ask at some point: "In what sense is this system naturalistic? In what sense is it metaphysical? How comes it that these two characters (which to me seem contradictory) can be united in this philosophy?" (673). Santayana's questions follow his own understanding of nature. As in many of his writings, reasonable assumptions build to unexpected 
conclusions. Santayana describes naturalism as "a primary system, or rather it is not a special system at all, but the spontaneous and inevitable body of beliefs involved in animal life." "This boyish universe," he continues, "is indefinitely extensible on its own plane; it may have heaven around it and fairyland in its interstices; it covers the whole field of possible material action to its uttermost reaches. It is the world of naturalism. On this material framework it is easy to hang all the immaterial objects, such as words, feelings, and ideas, which may be eventually distinguished in human experience" (674). Santayana's definition of nature works especially well in the context of traditional metaphysics. Nature is taken to be devoid of value in itself. Santayana distinguishes between material nature, and the immaterial realm of ideas which lend significance to it.

Clearly, Santayana understands the commonsense use of naturalism by Dewey and many others; his rendition of nature in explicitly non-naturalistic terms is predicated on his own Platonic dualism. Against nature, Santayana (1925) sets his definition of the metaphysical:

Naturalism will break down, however, so soon as words, ideas, or spirits are taken to be substantial on their own account, and powers at work prior to the existence of their organs, or independent of them. Now it is precisely such disembodied powers and immaterial functions prior to matter that are called metaphysical. Transcendentalism is not metaphysical as it remains a mere method, because then it might express the natural fact that any animal mind is its own center and must awake in order to know anything: it becomes metaphysical when this mind is said to be absolute, single, and without material conditions. To admit anything metaphysical in this sense is evidently to abandon naturalism. (674)

Santayana's description has little connection with the metaphysics Dewey recovers. One would be hard-pressed to find examples of "disembodied powers" and "immaterial functions" in Dewey. Likewise, Dewey does not argue that the human mind is "without material conditions." Instead, Dewey replaces mind-matter dualism with experience. Santayana (1925) recognizes this argument in Dewey, too: "There cannot be any actual mind in experience except the experience itself" (677). The definition Santayana offers both assumes and depends on a hard distinction between material nature and the realm of the absolute and ideal. He assumes that naturalism and metaphysics are mutually exclusive.

In order to defend against Dewey's inevitable rebuttal, Santayana (1925) presents nature in distinctly anti-Deweyan terms. "In nature there is no foreground or background, no here, no now, no moral cathedra, no centre so really central as to reduce all other things to mere margins and mere perspectives. A foreground is by definition relative to some chosen point of view, to the station assumed in the midst of nature by some creature tethered by fortune to a particular time and place. If such a foreground becomes dominant in a philosophy naturalism is abandoned" (678-79). ${ }^{3}$ While Santayana is correct that Dewey builds or enacts a metaphysics 
which takes human experience as its foreground, Dewey is nevertheless able to find value and meaning in nature without appealing to the supernatural. Dewey's reconstructed metaphysics is naturalistic, because of his recovery of the function of metaphysics as a way to locate value and meaning in and through experience.

This criticism of Dewey, and the misreading of experience, only make sense if we accept Santayana's (1925) claim that events in nature do not involve active participants, "just the flow of nature, the transit of an essence" (682). The perspective of the individual in nature is irrelevant for Santayana. According to him, nature is displaced in Dewey by history. Perhaps it is more accurate to say that Santayana's naturalism resists the potential and value of human experience. The language or metaphor of illusion, dream, image, and symbol dominate his description of the relation between nature and experience (Santayana 1921, 704, 705).

For Santayana (1925), nature trumps experience, and "laughs at our dialectic and goes on living in her own way" (682). Human existence is but a "waking dream" (684). Santayana (1921) embraces his idiosyncratic naturalism, claiming that it "is not at all afraid of the latest theories of space, time, or matter: what I understand of them, I like, and am ready to believe: for I am a follower of Plato in his doctrine that only knowledge of ideas (if we may call it knowledge) can be literal and exact, whilst practical knowledge is necessarily mythical in form, precisely because its object exists and is external to us" (706). The problem is not that Santayana gets Dewey wrong; the problem is that Santayana's naturalism, in Dewey's words, is "halfhearted," while his metaphysical commitments are dominant $(1927,57)$. Santayana enjoys the same rhetorical flourish in Platonism and the Spiritual Life (1957), where he writes: "For my purpose, however, it is fortunately unimportant to dispel these ambiguities, dear to half-hearted philosophies, because the Platonic doctrine at least is clear. If for the Platonist goods and evils are everlastingly fixed and distinct, this moral dogmatism in him is no accident of temperament, no mere lack of moral elasticity, as in the bigot. Life, he thinks, has been kindled and is alone sustained by the influence of pre-existing celestial models" (227). Santayana defends the Platonic conception of nature, but not the current conception of naturalism.

Dewey (1927) begins his reply by quoting Santayana's claim that "I am myself a dogmatic naturalist" (57). Santayana's naturalism, according to Dewey, "reduces itself to a vague gesture of adoring faith in some all-comprehensive unknowable in contrast with which all human life-barring this one gesture-is specious and illusory" (64). "In short," Dewey notes, "his presupposition is a break between nature and man; man in the sense of anything more than a physically extended body, man as institutions, culture, 'experience.' The former is real, substantial; the latter specious, deceptive, since it has centers and perspectives" (58). The alternative dualistic universe, in which mere matter and experience are both set against and dependent on an immaterial realm is "a hang-over of an intellectual convention which developed and flourished in physics at a particular stage of history" (58). Dewey's dogma is the insistence that ideals change, but must always emerge from and serve democratic culture. 
In his rebuttal to Santayana, Dewey (1927) repeatedly refers to his own naturalism as a method for understanding, solving (or dismissing) certain philosophical problems-including, centrally, the varieties of philosophical dualisms. He also repeats the claim made in Experience and Nature that experience does allow "any investigator who, by making certain observations and experiments, and by utilizing the existing body of ideas available for calculation and interpretation, [to conclude] that he really succeeds in finding out something about some limited aspect of nature" (59). In this sense, the foreground is "itself a portion of nature, an integral portion" and "nature is not just the dark abysmal unknown postulated by a religious faith in animality, especially since on such a view animality itself becomes a matter of faith" (60). Reviewing Santayana's Scepticism and Animal Faith in 1923, Dewey identifies this crucial and obvious difference:

It is also, under Mr. Santayana's hands, a thing of beauty for the philosopher for it enables him, when it is rightly envisaged, to become a complete and thorough sceptic as to direct knowledge of existence while it also opens to him an unshakable "cognitive certitude" - the being of essences which are the only thing worth knowing. For, as the acute reader of Mr. Santayana's moral writings is aware, existence is to him inherently ridiculous, for the physical basis and origin of ideal goods (and of course essence is ideal) is comically disparate to its ideal fruits. ([1923] 1983d, 223)

In his Ethics ([1932] 1985b), Dewey assumes just the opposite to be the case: "Moral conceptions and processes grow naturally out of the very conditions of human life" (308). Dewey's metaphysics is the vital tool with which he brings together the worlds of nature and mind Santayana keeps apart (Dewey 1927, 62). Dewey (1905a) offers that "the lesson learned, we can think freely and naïvely in terms of thingsbecause things are no longer entities in a world set over against another world called 'mind' or 'consciousness,' with some sort of mysterious ontological tie between them. Again, pragmatism has learned that the true meaning of subjectivism is just anti-dualism" (155). Detar suggests that the dualistic nature of what Dewey termed Santayana's "naturalistic idealism" is what most offended Dewey; for Dewey, nature was capable of generating values through human endeavors which draw on nature, including "religion, art, and science" (25-26). Santayana's dualism denudes nature and experience of their moral possibilities. For Dewey, pluralism stands on the recognition that "there are an indefinite multitude of heres, nows, and perspectives." In fact, Dewey (1927) argues, "to swallow them up in one all-embracing substance is, moreover, to make the latter unknowable; it is the logical premise of a complete agnosticism" (63). Dewey's metaphysics is not moralistic, but experimental. While it may work toward a recognition and development of moral ideals found through experience, these are never presented as final or absolute. One of the consequences of Santayana's dualistic universe is that it requires an appeal to fixed and permanent ideals which are non-negotiable and are thus unable to respond to the needs of humanity or democratic culture. The transcendent realm of ideals is antiscientific 
and nonprogressive. In short, Dewey recognizes in this approach a conservatism which does not allow ideals and values to be grounded in experience and subjected to experiment and negotiation-hence its agnosticism. He gives voice to the empiricist, whose "objection to the 'high a priori road' is that it introduces in irresponsible fashion a mode of presumed knowledge which may be used at any turn to stand sponsor for mere tradition and prejudice, and thus to nullify the results of science resting upon and verified by observable facts (Dewey 1906, 467).

\section{The Pragmatist Metaphysics Debate}

Some seventy-five years after Dewey and Santayana's exchanges, Charlene Haddock Seigfried has opened the new century inquiring about "the prospects of pragmatist metaphysics." Seigfried (2001) begins the most recent round in "Pragmatist Metaphysics? Why Terminology Matters." Her argument is straightforward: pragmatists "didn't just reject the traditional subject area of metaphysics. They grounded their analyses in the concrete conditions of everyday life. It is time to recognize that the formulation of these concrete conditions is a genuine alternative to metaphysics" (14). She blames the confusion about the pragmatists' rejection and replacement of metaphysics on their continuing "talk about what had been first conceived as metaphysical subjects." Seigfried notes that James and Dewey do not really mean God when they use the term, "but varieties of religious experience or a common faith" (14). Seigfried is undoubtedly right about Dewey. When he writes "God" in A Common Faith, he explicitly does not mean an all-powerful divine being. But his metaphysics runs deeper than his usage of the terminology of traditional metaphysics he criticizes throughout his work.

Seigfried is correct in her assessment of pragmatism, generally, and Dewey's hostility to traditional metaphysics, the epistemological turn in philosophy, and discussions of "the meaning of words," and so on. But she misses a great deal by claiming that Dewey in particular is interested solely in lived experience, and that any metaphysics returns us to a dualism Dewey so obviously rejects. Seigfried follows "Pragmatist Metaphysics?" with an extended essay focusing on Dewey, "Ghosts Walking Underground: Dewey’s Vanishing Metaphysics” (2004). Here she continues her dismissal of Deweyan metaphysics, making roughly the same two claims: Dewey is always critical of traditional metaphysics (and "plainly preferred other designations" for his own work); and no metaphysics could possibly fit the philosophical requirements of Dewey's pragmatism-if one did, it would no longer be metaphysical (53).

Perhaps the problem is with the terminology_instead of metaphysics, supernaturalist or -ism would be more appropriate. By metaphysical, I take it Seigfried means an appeal to something beyond experience. For her, metaphysics distinguishes between experience and an absolute ideal realm. She does not allow for any "weaker senses of metaphysics." This leads her to argue that all metaphysics displaces the pragmatist's attention on immediate experience and "the primary task of the 
intelligent transformation of given conditions toward better states of affairs" (2004, 54). When Seigfried uses the term metaphysical, it always represents an alternative to pragmatism which stands against science and resides in the supernatural, with its attendant dogmatic absolutism. This is what she calls "the metaphysical spirit" (55-56). Seigfried's refusal to acknowledge the possibility of a rival or reconstructed metaphysics allows her always to define it as appealing to fixed principles which would betray any sense of naturalist philosophy. But metaphysics does not always yield a "metaphysical principle," nor does it represent "something outside this process of human intelligence acting on natural events" (60-61). Dewey offers his metaphysics as the necessary tool which allows his naturalistic philosophy to effect the transformation of society. The primary task of the intelligent transformation of given conditions toward better states of affairs is impossible without the working of Dewey's metaphysics.

William T. Myers (2004), citing much of what caught my eye in "Pragmatist Metaphysics?," offers a weaker version of metaphysics when he argues that James and Dewey practice a form of nonfoundational metaphysics. In other words, he writes, "if by metaphysics one means the search for a 'first philosophy,' a search for foundations, for absolutes, for timeless truths, then, yes, [James, starting with the concrete] does indeed preclude that type of metaphysics" (42). Dewey, like James, rejects the foundational metaphysics which asks (and often answers) "what is the ultimate origin or cause of the universe?" (45). But while neither James nor Dewey has any patience for foundational metaphysics, both, Myers argues, are engaged in projects which seek to describe or explain the "generic traits of existence ... [or] the features of immediate experience" (48). While I largely agree with Myers, his defense does not sufficiently correct Seigfried's portrayal of Dewey.

More to the point, Dewey's metaphysics serves the very goals Seigfried identifies for Dewey and the pragmatists. On her reading, however, these purposes motivate the dismissal of metaphysics as a whole. Seigfried (2004) writes that "they saw the growing hegemony of positivist science as a threat to the values and beliefs that made us most benignly human. Religion and metaphysics, the older bulwarks against diminished human importance, were steadily eroding as sources of enlightened opposition to the reductive materialism science largely represented. The problem with metaphysics was that its speculations could not produce the evidential warrant that scientific progress was constantly producing and enlarging" (54). But Dewey does not offer his metaphysics as a foil to science, though Seigfried assumes any metaphysics would be only this. Dewey's metaphysics means to help science overcome the threat of becoming mere reductive materialism. The evidence of science and the force of naturalistic sciences generally do not compete with metaphysics, but are guided by it and so are made instrumental. Dewey does not introduce a "metaphysics of nature, rather than a naturalistic philosophical approach to particular experiences" as Seigfried writes (58). Rather, Dewey sees that naturalism requires a metaphysics - a discussion of the ideals located in nature and experience, which should guide science in the service of democracy. 
Citing Experience and Nature, Seigfried (2004) both acknowledges that Dewey "makes these common traits [of experience] the source of values and of their precariousness," and dismisses any value to identifying his work as pragmatist or naturalist metaphysics (70). Instead, she insists that the best and most helpful way of reading Dewey is as someone who "replace[s]" metaphysics with pragmatism. Because metaphysics always points away from experience, and always implies or requires a dualism, there is no valuable metaphysics for Seigfried. Dewey's metaphysics, as he argues, does neither.

As John Shook (2004) points out, Dewey’s metaphysics does not "look like metaphysics" to most philosophers; "where are the a priori premises, for example?" (731). For Shook, Dewey's naturalism is empirical and his metaphysics pragmatic. Dewey does not, according to Shook, "inquire after any experience-independent reality" (732). Responding to critics of the "metaphysical Dewey," Shook attempts to reshape the terms of the debate: "Dewey accepted [that nature extends beyond actual experience] because we do experience things as persisting while not being experienced (due to learning in infancy), and also as a matter of useful hypothesis for the advanced sort of learning called science." This does not mean, however, that Dewey "draw $[\mathrm{s}]$ conclusions about transcendent matters permanently beyond experience" $(735,736){ }^{4}$

\section{Metaphysics and Education}

Those who reject Dewey's metaphysics particularly disavow any sense of the ideal in Dewey. This is the most relevant aspect of his metaphysics for discussions of education. The critical response to Victor Kestenbaum's The Grace and the Severity of the Ideal: John Dewey and the Transcendent (2002) is informative. Many reviewers insist that Dewey does not imagine "an ideal realm of supersensible entities"-as Kestenbaum maintains in his reading of A Common Faith. If Dewey does point to a realm beyond experience, then his metaphysics would indeed be quite traditional. Instead, his crucial insight is that ideals emerge through experience as they guide it; they are elements of nature which do not, then, point toward or originate in the supernatural. The trick to reading Dewey-and responding to Kestenbaum-is to allow Dewey to naturalize metaphysics. Shane Ralston argues that the religious for Dewey does not open one to a transcendental reality. He writes:

In naturalized terms, faith in the religious quality of experience is an inquirer's capacity to adapt to the environment by changing his or her attitudes; likewise, faith in ideality is merely the imagined outcome of transforming an experienced situation in fruitful ways. Thus, for the Dewey scholar, plenty of evidence can be found in "Religion versus the Religious" [the opening chapter of A Common Faith] to support the claim, contra Kestenbaum, that faith in the religious and ideal qualities of experience should be understood in wholly naturalistic and instrumental terms. $(66,67)$ 
Kestenbaum (2002) typically argues: "Dewey decisively rejects the naturalistic hope or expectation that by 'unseen powers' he simply means what has yet to be made visible, seeable, sensible. No. We address the unseen and invisible through faith, and faith is not the anticipation of an eventual visibility" (183). It is ironic that Kestenbaum's Dewey is more like Santayana than Santayana himself recognized.

It should not be surprising that Ralston's defense of Dewey, and another by Christine McCarthy, appear in education journals. Dewey cannot advocate for a reconstructed metaphysics, a democratic pedagogy based on experiential learning, and recognize a realm of fixed, transcendental ideals or principles which should guide education (though he does seem to celebrate the ideal of democracy). McCarthy's critique of Kestenbaum is particularly pointed:

"Transcending" experience, in either a Kantian or a Platonic sense, is in Dewey's view an exceedingly bad idea. A belief that one has transcended experience, has "risen above" it, escaped its constraints, and is no longer limited by it, is a recipe for disaster. For without the limits and constraints of experience, one has no possible way to separate true beliefs from false beliefs. One would then be in the condition Kestenbaum lauds, possessed of an imagination that is "unreconciled to actuality." Having thus freed oneself from the only means of discovering truths, one's beliefs can only be unwarranted. Whether one goes on to accept with docility the fixed principles and unverifiable dogmas of those who claim to have seen "reality as it is" or whether one strikes out bravely to create meaning de novo without worrying about truth, the consequences for social life are not good. $(350)^{5}$

Kestenbaum's (2002) finding, that Dewey's "pragmatism has found it necessary to bracket existence and to imagine regulative ideals which cannot be traced back to an individual's, society's, or culture's practices and the evidences they afford," offends McCarthy and Ralston (179). Dewey has a metaphysics; but he has no use for the traditional metaphysics Kestenbaum describes.

While most defenses of Dewey's metaphysics begin and end in the pages of Experience and Nature, a brief review of this and other pieces drawn from works both early and late, including his writings on education, allows me to make a strong case for a reconstructed metaphysics at the heart of Dewey's instrumentalism, as practically applied in his work on education. In the last chapter of Experience and Nature, "Existence, Value, and Criticism," Dewey (1949) introduces his "metaphysical” belief that "the natural world has generic as well as specific traits, and that in the one case as in the other experience is such as to enable us to arrive at their identification" (713). ${ }^{6}$ His argument, appearing in a late rebuttal to yet another misinterpreter, is that experience does reveal or open one to general or generic traits which themselves are open to criticism, specifically of "values as concrete events." Dewey writes, "the entire discussion, while short, is given to showing that the sense and point of recognition of generic traits lies in their application in the conduct of life: that is, in their moral bearing provided moral can be taken in its basic broad human sense" (713). 
Metaphysics is the seeing of value in incompleteness and progress. It represents for Dewey the only alternative to dogmatism, positivism, and materialism.

We find this argument in support of the location of ideals in and through experience throughout Dewey's writings on education. His basic premise is that education and democracy are reciprocal. This claim has practical consequences for the classroom: "Learning which develops intelligence and character does not come about when only the textbook and the teacher have a say; that every individual becomes educated only as he has an opportunity to contribute something from his own experience, no matter how meagre or slender that background of experience may be at a given time; and finally that enlightenment comes from the give and take, from the exchange of experiences and ideas" ([1938] 1988b, 294, 296). The two alternatives to Dewey's naturalistic metaphysics, traditional metaphysics and positivism, both fail to reflect properly the value of experience. They are reflected in a similar educational method, which either denies the possibility of moral education through classroom experience, or dislocates values from the discovery of facts. A similarly harmful alternative is the antidemocratic and nationalistic educational system which imbues students with a set of non-negotiable values, whose purpose is to drive support of the nation. Other examples in education which fit the category of traditional metaphysics include religious dogma and private religious instruction, both of which might distinguish between the pluralism of democratic culture and the transcendence and singularity of religious belief. Part of Dewey's reconstruction of metaphysics is the recovery of belief and its application in a democratic context. Experience and Education begins with a description of the difference between "traditional" and "progressive" education. The approach which parallels that of traditional metaphysics provides "standards and rules of conduct; moral training consists in forming habits of action in conformity with these rules and standards" ([1938] 1988a, 5). Dewey warns that "the failure to give constant attention to development of the intellectual content of experiences and to obtain ever-increasing organization of facts and ideas may in the end merely strengthen the tendency toward a reactionary return to intellectual and moral authoritarianism" (58). The alternative offers the "intelligently directed development of the possibilities inherent in ordinary experience" (61).

In "Philosophy and American National Life" (1905), Dewey sets American philosophy against "Materialism" and "Mechanicalism," and the "phenomena" of "positive observation" ([1905] 1983a, 74, 5). He argues that the ultimate questions of philosophy are meant to serve "the needs of democracy in America" (74). To achieve this, philosophy must become metaphysical, though in a new way; Dewey writes, "it means that in some very true sense the individual with which psychology deals now is an ultimate; and that henceforth the metaphysical question of the nature and significance of the individual is bound up with the scientific problem of his actual structure and behavior" (75). Before this brief quote is taken to set metaphysics against science, it is worth noting that Dewey clearly defines his method, 
and that "which must characterize American thought," as reflecting "an absence of dogmatism, of rigidly fixed doctrines," while presenting "a certain fluidity and socially experimental quality" (76). Instrumentalism, for Dewey, is antithetical to a "final" philosophy, and does not establish "any particular set of truths" (77).

Metaphysics, in its positive use by Dewey, represents an examination of meaning and value through experience and experimentation. In his 1906 essay "Beliefs and Realities," Dewey presses his naturalist case that "to believe is to ascribe value, impute meaning, assign import ... It means here and now, not in some transcendent sphere" ([1906] 1983b, 83). "For the world has meaning," Dewey explains, "as somebody's, somebody's at a juncture, taken for better or worse, and you shall not have completed your metaphysics till you have told whose world is meant and how and what for-in what bias and to what effect. Here is a cake that is had only by eating it, just as there is digestion only for life as well as by life" (84). This brand of metaphysics provides an alternative both to traditional metaphysics which looks beyond experience to find a meaning pregiven in a transcendental realm, and to the "Stoic dogma" of professional philosophical epistemology. Here, the terms are interchangeable: the errors of traditional epistemology are found, too, in the positivist conception of the possibilities and metaphysical assumptions of science. While Dewey may have developed a straw-man version of science, he finds that it too often detaches value from fact. Dewey spares little in his critique of recent trends in philosophy which posit an alternate reality against "the standpoint of the common man ... passionless imperturbability, absolute detachment, complete subjection to a ready-made and finished reality - physical it may be, mental it may be, logical it may be-is its professed ideal. Forswearing the reality of affection, and the gallantry of adventure, the genuineness of the incomplete, the tentative, it has taken an oath of allegiance to Reality, objective, universal, complete; made perhaps of atoms, perhaps of sensations, perhaps of logical meanings" (85). The failure to recognize the inherence of value in experience and nature (or culture) has led, Dewey writes some forty years later, to the "deeply entrenched and fortified habit of treating economic affairs, industry, trade, and business, as mere means having no intrinsic connection with 'ultimate' ends which are moral ... Separation of the 'materialistic' and the 'ideal' deprives the latter of leverage and impetus, and prevents the things to which the former name is applied from rendering the humane service of which they are capable" ([1944] 1989b, 167).

The strengthening of beliefs (which guide behavior) requires "the union of acknowledgment of moral powers and demands with thoroughgoing naturalism." The notion of a naturalistic metaphysics does not give Dewey pause. Instead he argues that both serve each other: "If beliefs are the most natural, and in that sense, the most metaphysical of all things, and if knowledge is an organized technique for working out their implications and interrelations, for directing their formation and employ, how unnecessary, how petty the dear and the caution" ([1924] 1983b, 98-99). Detaching the discussion of values from inquiry, whether scientific or philosophical, produces the same end as relegating values to a transcendent realm that 
is in many ways beyond ordinary human discourse. The duty of education, which Dewey ties to its proper method, is in large part grounded in its service to democracy and participatory democratic engagement: it must help students develop the ability to express, discuss, and develop their moral reasoning.

Deweyan pragmatism, charged with the task of serving democracy, adopts the moral function of the metaphysical when it directs the "general concepts or ideas" drawn from experience toward "organizing future observations and experiences" ([1925] 1984a, 12). Dewey labels this pragmatism's "metaphysical implication." He writes, "the doctrine of the value of consequences leads us to take the future into consideration. And this taking into consideration of the future takes us to the conception of a universe whose evolution is not finished, of a universe which is still, in James' term, 'in the making,' 'in the process of becoming,' of a universe up to a certain point still plastic" (13). Instrumentalism, unlike traditional empiricism, materialism, and the version of science which Dewey dismisses, looks forward with the task of "reconstructing the present stage of things instead of merely knowing it" (18). Clearly for Dewey, metaphysics makes his empiricism instrumental and reflects the mutuality of his progressive philosophies of education and democracy.

Nowhere is this more evident than in the pages of Democracy and Education, where Dewey reconstructs traditional approaches in education. Just as philosophical metaphysics often identifies the ideal as fixed and unchanging, and offers access to it through abstract reason alone, traditional education provides knowledge detached from the kind of forward-looking, melioristic, and experiential learning that Dewey supports. The practical effect of Dewey's critique of metaphysics, as well as his recovery of its function is expressed succinctly in the concluding chapter, "Theories of Morals":

Moral knowledge is thought to be a thing apart, and conscience is thought of as something radically different from consciousness. This separation, if valid, is of especial significance for education. Moral education in school is practically hopeless when we set up the development of character as a supreme end, and at the same time treat the acquiring of knowledge and the development of understanding, which of necessity occupy the chief part of school time, as having nothing to do with character. On such a basis, moral education is inevitably reduced to some kind of catechetical instruction. ([1916] 1985a, 364)

Moral education only works to support democratic culture when values and the methods used for the students who learn them are tested, experienced, debated, and often revised. Students must be able to think through moral problems and devise solutions. Training students involves developing their character-and this is not achieved when scientific knowledge is detached from moral knowledge. Likewise, students who are offered set rules and fixed principles receive the weakest form of moral education: they are presented with truths, and are unprepared to test them through experience. 


\section{Conclusions}

The experience of nature on which Dewey builds is Emersonian in spirit. While this conclusion might bring me precariously close to adding yet another sense of the metaphysical-as something akin to religious or religiose-Dewey's conception of nature and the experience of nature never leads away from nature itself and always serves his larger democratic project. At the end of Quest for Certainty, the Gifford Lectures Dewey delivered in 1929, four years after the first publication of Experience and Nature and the same year as their revision and republication, he identifies the experience of nature as the path to a kind of pragmatic "religious faith." In a passage which paints a romantic portrait of the possibilities of nature and brings to mind A Common Faith, Dewey writes:

Aspiration and endeavor are not ends in themselves; value is not in them in isolation but in them as means to that reorganization of the existent in which approved meanings are attained. Nature and society include within themselves projection of ideal possibilities and contain the operations by which they are actualized. Nature may not be worshiped as divine even in the sense of the intellectual love of Spinoza. But nature, including humanity, with all its defects and imperfections, may evoke heartfelt piety as the source of ideals, of possibilities, of aspiration in their behalf, and as the eventual abode of all attained goods and excellencies. (1929b, 306)

P. Eddy Wilson points to A Common Faith as the text in which Dewey introduces "natural piety" (329). But it seems to be in play in Experience and Nature, and certainly in The Quest for Certainty. Wilson also connects Dewey's naturalism with Emerson, arguing that both hold that "the person who reflectively reveres nature and who manifests that reverence for nature in practical activity is a practitioner of natural piety." There is a difference, though: "Emerson's description of natural piety is religious, and the reverence for nature it inspires is metaphysically grounded. Dewey's description of natural piety makes use of an instrumental view of religiousness, and the reverence for nature it inspires is subject to instrumental criteria" (345). Wilson notes that Dewey does not retain the transcendental commitments we might find in Emerson and James. But experience, for Dewey, does bring forth a metaphysics as it, according to Thomas Gardner, leads to the disclosure of the "fundamental characteristics of nature" (394). "The generic traits of natural existence as disclosed by experience" provide the content of Dewey's metaphysics which serves to direct the moral goods of experience toward the betterment of society (395). ${ }^{7}$ Piety which is mere allegiance to an absolute, or which seeks fulfillment through a set of principles beyond challenge, mimics philosophical metaphysics which posits reality in an ideal or supernatural realm. Natural piety, like naturalistic metaphysics, locates value and meaning through experience and cooperative inquiry. Dewey also refers to this kind of piety as "democratic faith." In an article published the same month as the Normandy Invasion, Dewey dismisses in the strongest possible terms 
the belief "that something called 'natural law' could be trusted, with only incidental cooperation by human beings, to bring about the desired ends." He continues:

The lesson to be learned is that human attitudes and efforts are the strategic centre for promotion of the generous aims of peace among nations; promotion of economic security; the use of political means in order to advance freedom and equality; and the worldwide cause of democratic institutions. Anyone who starts from this premise is bound to see that it carries with it the basic importance of education in creating the habits and the outlook that are able and eager to secure the ends of peace, democracy, and economic stability." ([1944] 1989b, 257)

Two recent books bring connect Dewey's work in philosophy and education with his commitment to democracy: Melvin Rogers's The Undiscovered Dewey: Religion, Morality, and the Ethos of Democracy, and Gregory Fernando Pappas's John Dewey's Ethics: Democracy as Experience. Rogers adopts Dewey's use of "democratic faith," and argues that "Dewey's understanding of religious naturalism [allows that] nature-broadly conceived — can generate both a sense of piety and a guiding faith in life without requiring a supernatural source for their intelligibility. Piety cannot mean blind deference as we traditionally understand the term. Rather, piety is a critical but retrospective assessment of the narrative of experience we inhabit and on which we depend; it allows us to deepen our apprehension of the present" (2009a, 108, 109).

This common-sense reading of Dewey is echoed in Gregory Pappas's book. Pappas dismisses the linguistic turn in philosophy, and its specific application in moral thought, by recovering the rich conception of experience in Dewey (39). His Dewey takes into full account the lived contexts of moral dilemmas and offers philosophy as a form of criticism which examines its moral work from inside, without recourse to an objective perspective or appeal to fixed and unchanging ideals (40,65-68). Pappas moves Dewey beyond Putnam and Rorty by recovering the very approach Dewey defends against Santayana.

Clearly, in his exchange with Santayana, Dewey rejects a metaphysics which locates meaning and value in something static and beyond. Santayana defends an absolutism that Dewey rejects. Dewey's naturalism, however, is not antimetaphysical; it is antisupernaturalism, anti any ism which places truths beyond experience and critique. Dewey's brand of metaphysics provides a socially constructed ideal which incorporates the kind of hypothesizing and testing which makes most naturalisms naturalistic. This, too, is the core of his progressive approach in education: Developing the ability to reason critically and to act morally-both of which are crucial to the welfare of democratic culture-requires a kind of training that can only be found through experiential learning.

What then is the value of defending Dewey's naturalistic metaphysics? Seigfried (2004) poses the question in these terms: 
What is odd is combining "metaphysics" with the adjective, "naturalistic," given the sweeping rejections entailed in Dewey's emphatic use of the adjective. He is certainly rejecting supernaturalism in all its forms as well as transcendentalism. But could not one call his turn to nature the very essence of his naturalistic metaphysics? That all depends on the way he appeals to nature. Scientific inquiry into nature no more makes scientists' work metaphysical than travelogues about natural features of landscapes do. Dewey is determined to pursue inquiries into nature in a scientific rather than metaphysical spirit. (54)

Dewey replaces metaphysics with "an account of the bio-historical development of minded organisms in social and natural environments, an account informed and guided by care and concern for the quality of the transaction." This, coupled with the "call and challenge" of experience for Dewey, leads Seigfried to conclude that "such a deeply existentialist explanation of change takes us very far from a metaphysics of being, or 'what is,' or what is becoming, to lived experience as the relevant locus of reflection." Simply put, then, Dewey is "post-metaphysical” (54).

We must ask if it is particularly valuable, then, to correct Seigfried (2004) when she rightly points out that "metaphysics . . . takes as its aim the reconciliation or triumph of a perfect realm of being with or over the inferior world of appearance, illusion, and confusing facts." This is undoubtedly one of the varieties of metaphysics, and not at all the type attributed to Dewey. Seigfried is convinced that thinking "of his project as a pragmatist metaphysics" is not at all "the best way to capture the enormity, profundity, and fertility of Dewey's original analysis of the human condition after Darwin" $(59,61,68,70)$. Respectfully, I disagree. Dewey's naturalistic metaphysics is more than a new way of talking about an old way of thinking. Reading Dewey stripped of his metaphysics misses what makes his empiricism instrumental. Even as it moves beyond the individual toward the communal and cultural, Dewey's metaphysics remains grounded in nature; it depends on science, experimentation, and human experience. When she writes that "Dewey is determined to pursue inquiries into nature in a scientific rather than metaphysical spirit," Seigfried overlooks the function of reconstructed metaphysics, and its necessary role in making science nonpositivistic. For Dewey, a naturalistic metaphysics animates and guides science, as well as education.

Seigfried and others often note that Dewey himself suggested that he might have replaced "experience" with "culture," in the title of Experience and Nature. Seigfried (2001) concludes from this that "it is not insignificant that what is presumed to be his metaphysical work is called by him Experience and Nature, not a Metaphysics of Experience and Nature. Against many subsequent criticisms, he did not make any supposed metaphysical underpinnings more explicit, but tried to avoid misunderstandings by proposing a title even less likely to be confused with metaphysics, namely Culture and Nature. And yet, for lack of a better term, the temptation remains to call the brilliant analyses in this book, which provide a 
background for his logic of inquiry, a metaphysics" (15). Dewey's regret at how his use of "metaphysics" is frequently misunderstood is not proof that he does not offer a metaphysics. His suggestion that "culture" replace "experience" does nothing to unseat the meaning of his usage of experience or the focus on "the generalized view of 'experience' in Experience and Nature" (Dewey 1949, 711). He explicitly blames the misunderstanding on those who assume that "I regard philosophical and metaphysical as synonyms; or, at least, treat metaphysics as a name for that part of philosophy that is concerned with the relation of experience to existence, and, furthermore, that I use the word metaphysical in the sense it bears in the classic tradition based on Aristotle. Nothing could be farther from the facts of the case" (712).

Dewey intends to make sense of "metaphysics and metaphysical ... on experiential grounds, instead of upon the ground of ultimate Being behind experience serving as its under-pinning" (712). In fact, he insists that "this genuine subject matter is the fact that the natural world has generic as well as specific traits, and that in the one case as in the other experience is such as to enable us to arrive at their identification. The entire discussion of generic traits lies in their application in the conduct of life: that is, in their moral bearing provided moral be taken in its basic broad human sense" (713). Lest Dewey be misunderstood, he does distinguish between philosophy and metaphysics. He makes this point to emphasize the usefulness and function of reconstructed metaphysics. He concludes, "the foregoing is not an apology for my use of the word 'metaphysical.' It is evoked by the misreading of my use of that word, which probably is not confined to Mr. Kahn" (713).

Dewey's naturalistic metaphysics involves both a critique of philosophy and a declaration of the imperative that pragmatism turn to experience with a scientist's eye and a democrat's concern for the improvement of society as a whole. The moral and democratic cause of Dewey's pragmatism is lost if his metaphysics is either dismissed or diminished. As critique, Dewey's approach offers a way beyond any metaphysics which points away from experience and toward the supernatural. ${ }^{8}$ As metaphysics, Dewey's work emphasizes the tasks still left to philosophy, the methods available to education, and the centrality of the human endeavor to these disciplines.

\section{Acknowledgment}

In honor of my teacher, Mr. David A. Johnson.

\section{Notes}

1. Boisvert offers a clear and detailed differentiation between Aristotle and Dewey's metaphysics. See esp. chapter 4, "Dewey's Objections to Traditional Doctrines."

2. Sleeper cites John Herman Randall, Jr's Nature and Historical Experience (New York: Columbia University Press, 1958), 125.

3. This parallels Santayana's critique of Emerson. See Levinson, 113-14: "Emerson, Santayana concludes, leaves us with a complex religious vision of the promise and problems of human life, but one that still adds up to a religion of illusions, not the 'religion of disillusion' Santayana wants. What is needed, he says, is a religion that suffers neither from Emer- 
son's flight from tradition taken as a source of authority, nor from his worn-out attempt to make contact with absolute reality, nor from his infatuation with poetic self-assertion, nor from the self-deceptions involved in identifying his own self, race, and country with God."

4. Shook (2004) is quick to point out that while experience may be absolute for Dewey, "this is not meant in the ontological sense of the idealists who wanted all existence to be within experience, but rather in the methodological sense that only experience ultimately supplies meaning to our intellectual pursuits, including metaphysics" (741-42). Shook's description of Dewey paints him as phenomenalistic, that is, denying the existence of things in themselves and identifying reality with what is or can be experienced. Dewey, successfully or not, always tries to move beyond what he finds to be unhelpful (often dualistic) philosophical theories. When asked whether his "metaphysics include[s] any existence beyond experience," Dewey (1949) answers, "my philosophical view, or theory, of experience does not include any existence beyond the reach of experience" (709). Elsewhere he writes, "speaking of the matter only for myself, the presuppositions and tendencies of pragmatism are distinctly realistic" $(1905,324)$.

5. For Kestenbaum's response, see Kestenbaum, 2007.

6. His article is in response to S. J. Kahn's "Experience and Existence in Dewey's Naturalistic Metaphysics," Philosophy and Phenomenological Research 9, no. 2 (1948): 316-21.

7. Gardner examines the question of whether Dewey's empirical naturalism provides a metaphysics of existence or a metaphysics of experience. Gardner rejects the basis of the question: “A proper understanding of Dewey's metaphysics undermines the very foundation of this debate. I contend that Dewey would accept neither the position that Sleeper attributes to him [existence] nor the position that Hook and Stuhr attribute to him [experience], because both of these positions imply a distinction between existence (or nature) and experience that Dewey takes great pains to reject" (399). A version of this debate is found in exchanges between Sholom J. Kahn and Dewey (see Kahn 1948; Dewey 1949).

For a discussion of the differences between Santayana's "Spiritual Liberalism" and Dewey's "Common Faith," see Levinson 251-60.

8. See Boisvert, especially section 3. "Change and Permanence in the Experimental Logic." Boisvert is critical of Rorty and Hook's dismissal of Dewey's attempts "to articulate a metaphysics consistent with the discoveries of modern science" (5). Gale (2002), too, emphasizes the critical aspects of Dewey's metaphysics.

\section{References}

Alexander, Thomas. 1992. "Dewey and the Metaphysical Imagination." Transactions of the Charles S. Peirce Society 28, no. 2: 203-15.

Baert, Patrick. 2003. "Pragmatism, Realism and Hermeneutics." Foundations of Science 8: 89-106.

Bernstein, Richard. 1961. “John Dewey's Metaphysics of Experience.” The Journal of Philosophy 58, no. 1: 5-14.

Biesta, Gert J. J. 2009. "How to Use Pragmatism Pragmatically? Suggestions for the Twenty-First Century." Education and Culture 25, no. 2: 34-45.

Boisvert, Raymond D. 1988. Dewey's Metaphysics. New York: Fordham University Press.

———. 1998. John Dewey: Rethinking our Time. (Albany: State University of New York Press). 
Campbell, James. 2007. "One Hundred Years of Pragmatism." Transactions of the Charles S. Peirce Society 43, no. 1: 1-11.

Richard, Detar. 1996. “The Rival Naturalisms of Dewey and Santayana.” Bulletin of the Santayana Society 14: 24-33.

Dewey, John. 1906. "Experience and Objective Idealism.” The Philosophical Review 15, no. 5: 465-81.

- - - 1923. "Review of The Life of Reason, or the Phases of Human Progress by George Santayana.” Science (New Series) 23, 580: 223-25.

_-_. 1927. "Half-Hearted Naturalism." The Journal of Philosophy 24, no. 3: 57-64.

_-_. 1929a. Experience and Nature. 2nd ed. La Salle: Open Court.

- - . 1929b. The Quest for Certainty: A Study of the Relation of Knowledge and Action. New York: Minton, Balch.

_-_. 1940. "Nature in Experience." The Philosophical Review 49, no. 2: 244-58.

_-_. 1949. "Experience and Existence: A Comment." Philosophy and Phenomenological Research 9, no. 4: 709-13.

___. 1969. “The Metaphysical Assumptions of Materialism.” 1882. In The Early Works, v. 1, ed. Jo Ann Boydston. Carbondale: Southern Illinois University Press, 3-8.

_-_. 1983a. "Philosophy and American National Life." 1905. In The Middle Works. Vol. 3, edited by Jo Ann Boydston, 73-78. Carbondale: Southern Illinois University Press.

___. 1983b. "Beliefs and Realities." 1906. In The Middle Works Vol. 3, edited by Jo Ann Boydston, 83-100. Carbondale: Southern Illinois University Press.

_-_. 1983c. “The Realism of Pragmatism.” 1905. In The Middle Works. Vol. 3, edited by Jo Ann Boydston, 153-57. Carbondale: Southern Illinois University Press.

-_- . 1983d. "Review of Scepticism and Animal Faith: Introduction to a System of Philosophy by George Santayana. New York: Charles Scribner’s Sons.” 1923. In The Middle Works. Vol. 15, edited by Jo Ann Boydston, 223-25. Carbondale: Southern Illinois University Press.

_-_. 1984a. “The Development of American Pragmatism." 1925. In The Later Works. Vol. 2, edited by Jo Ann Boydston, 3-21. Carbondale: Southern Illinois University Press.

_- _. 1984b. “The Sources of a Science of Education." 1929. in The Later Works. Vol. 5, edited by Jo Ann Boydston, 3-40. Carbondale: Southern Illinois University Press.

_- _. 1984c. "From Absolutism to Experimentalism." 1930. In The Later Works. Vol. 5, edited Jo Ann Boydston, 147-60. Carbondale: Southern Illinois University Press.

_-_. 1985a. Democracy and Education. 1916. In The Middle Works. Vol. 9, edited by Jo Ann Boydston. Carbondale: Southern Illinois University Press.

—_- 1985b. Ethics. 1932. in The Later Works. Vol. 7, edited by Jo Ann Boydston. Carbondale: Southern Illinois University Press. 
-_- 1988a. Experience and Education. 1938. In The Later Works. Vol. 13, edited by Jo Ann Boydston, 1-62. Carbondale: Southern Illinois University Press.

_-_. 1988b. "Democracy and Education in the World of Today." 1938. In The Later Works. Vol. 13, edited by Jo Ann Boydston, 294-303. Carbondale: Southern Illinois University Press.

_-_. 1989a. "Introduction to Problems of Men: The Problems of Men and the Present State of Philosophy." 1946. In The Later Works. Vol. 15, edited by Jo Ann Boydston, 154-69. Carbondale: Southern Illinois University Press.

_- _. 1989b. “The Democratic Faith and Education." 1944. In The Later Works. Vol. 15, edited by Jo Ann Boydston, 154-69. Carbondale: Southern Illinois University Press.

-_- 2007. Essays in Experimental Logic. Edited by D. Micah Hester and Robert B. Talisse. Carbondale: Southern Illinois University Press.

Dilworth, David A. 2003. “Santayana's Review of Dewey's Experience and Nature: Pivotal Expression of a Philosophy of Living Nature and Vivacious Spirit." Bulletin of the Santayana Society 21: 15-30.

Gale, Richard M. 1997. “John Dewey's Naturalization of William James.” In The Cambridge Companion to William James, edited by Ruth Anna Putnam. Cambridge: Cambridge University Press. 49-68.

_-_ 2002. "The Metaphysics of John Dewey." Transactions of the Charles S. Peirce Society 38, no. 4: 477-519.

- - - 2004. "The Still Divided Self of William James." Transactions of the Charles S. Peirce Society 36, no. 3: 153-70.

_-_. 2004. "William James and John Dewey: The Odd Couple." Midwest Studies in Philosophy 28: 149-67.

Gardner, Thomas. 2000. “The Subject Matter of Dewey's Metaphysics.” Transactions of the Charles S. Peirce Society 40, no. 1: 393-405.

Gitre, Edward J. K. 2006. "William James on Divine Intimacy: Psychical Research, Cosmological Realism and a Circumscribed Re-reading of the Varieties of Religious Experience." History of the Human Sciences 19, no. 1: 1-21.

Godfrey-Smith, Peter. 2002. "Dewey on Naturalism, Realism and Science." Philosophy of Science 69, no. 3: S25-S35.

Gouinlock, James. 1972. John Dewey's Philosophy of Value. New York: Humanities Press.

Haack, Susan. 1987. “Realism.” Synthese 73, no. 2: 275-99.

Harris, Fred. 2007. "Dewey's Concepts of Stability and Precariousness in his Philosophy of Education." Education and Culture 23, no. 1: 38-54.

Hewitt, Randall S. 2006. "Democratic Education: A Deweyan Reminder." Education and Culture 22, no. 2: 43-60.

Hildebrand, David L. 2003. Beyond Realism and Anti-Realism: John Dewey and the Neo-Pragmatists. Nashville: Vanderbilt University Press.

Kahn, Sholom J. 1948. "Experience and Existence in Dewey's Naturalistic Metaphysics." Philosophy and Phenomenological Research 9, no. 2: 316-21. 
Kestenbaum, Victor. 2002. The Grace and Severity of the Ideal: John Dewey and the Transcendent. Chicago: University of Chicago Press.

_-_. 2007. "Natural Enough: A Response to McCarthy." Studies in Philosophy and Education 26, no. 4: 363-76.

Kim, Jiwon. 2009. "Dewey's Aesthetics and Today's Moral Education." Education and Culture 25, no. 2: 62-75.

Levinson, Henry Samuel. 1992. Santayana, Pragmatism, and the Spiritual Life. Chapel Hill: University of North Carolina Press.

Lovejoy, Arthur O. 1909. "Pragmatism and Realism." Journal of Philosophy, Psychology and Scientific Methods 6, no. 21: 575-80.

Manicas, Peter. 2008. Rescuing Dewey: Essays in Pragmatic Naturalism. New York: Lexington Books.

Mayer, Susan Jean. 2007. “The Ideal as Real: John Dewey and the Social Construction of Moral Coherence." Journal of Curriculum and Pedagogy 4, no. 2: 176-86.

McCarthy, Christine L. 2007. "The Quest for Transcendence in Dewey's Pragmatism, or, the View Not Held." Review of The Grace and the Severity of the Ideal: John Dewey and the Transcendent, by Victor Kestenbaum. Studies in Philosophy and Education 26, no. 4: 345-62.

Myers, William T. 2004. "Pragmatist Metaphysics: A Defense." Transactions of the Charles S. Peirce Society 40, no. 1: 39-52

Neiman, Alven. 1996. "Rorty's Dewey: Pragmatism, Education and the Public Sphere." Studies in Philosophy and Education 15, nos. 1-2: 121-29.

Noddings, Nel. 1998. “Thoughts on John Dewey's 'Ethical Principals Underlying Education." The Elementary School Journal 98, no. 5: 479-88.

Pappas, Gregory Fernando. 2008. John Dewey's Ethics: Democracy as Experience. Bloomington: Indiana University Press.

Pawelski, James O. 2003. "William James's Divided Self and the Process of its Unification: A Reply to Richard Gale." Transactions of the Charles S. Peirce Society 39, no. 4: 645-56.

Perry, Ralph Barton. 1915. "Dr. Schiller on William James and Realism.” Mind 24, no. 94: 240-49.

Phillips, D. C. 1998. “John Dewey's The Child and the Curriculum: A Century Later." The Elementary School Journal 98, no. 5: 403-14.

Pihlström, Sami. 2007. "Metaphysics with a Human Face: William James and the Prospects of Pragmatist Metaphysics.” William James Studies 2, no. 1. http:// williamjamesstudies.org/2.1/pihlstrom.html

Prawat, Richard S. 2003. “The Nominalism versus Realism Debate: Toward a Philosophical Rather than a Political Resolution." Educational Theory 53, no. 3: 275-311.

Proudfoot, Wayne. 2000. "William James on an Unseen Order." The Harvard Theological Review 93, no. 1: 51-66. 
Ralston, Shane. 2007. "John Dewey "on the side of the angels": A Critique of

Kestenbaum's Phenomenological Reading of A Common Faith." Education and Culture 23, no. 2: 63-75.

Randall, John Herman, Jr. 1946. "Metaphysics: Its Function, Consequences, and Criteria." The Journal of Philosophy 43, no. 15: 401-12.

Rogers, Melvin L. 2007. "Action and Inquiry in Dewey's Philosophy." Transactions of the Charles S. Peirce Society 43, no. 1: 90-115.

- - . 2009a. The Undiscovered Dewey: Religion, Morality, and the Ethos of Democracy. New York: Columbia University Press.

_-_. 2009b "Dewey, Pluralism, and Democracy: A Response to Robert Talisse."

Transactions of the Charles S. Peirce Society 45, no. 1: 75-79.

Rorty, Richard. 1979. Philosophy and the Mirror of Nature. Princeton: Princeton University Press.

___ . 1982. Consequences of Pragmatism. Minneapolis: University of Minnesota Press.

-_- 1999. Philosophy and Social Hope. New York: Penguin Books.

Rosenberg, Alex. 1996. "A Field Guide to Recent Species of Naturalism." The British Journal for the Philosophy of Science 47, no. 1: 1-29.

Saito, Naoko. 2009. "Reconstruction in Dewey's Pragmatism: Home, Neighborhood, and Otherness." Education and Culture 25, no. 2: 101-14.

Santayana, George. 1921. "On My Friendly Critics." The Journal of Philosophy 18, no. 26: 701-13.

_-_. 1925. "Dewey's Naturalistic Metaphysics." The Journal of Philosophy 22, no. 25 : 673-88.

-_- 1957. Winds of Doctrine and Platonism and the Spiritual Life. New York: Harper and Brothers.

Schiller, F. C. S. 1905. “The Definition of 'Pragmatism' and 'Humanism.” Mind 14, no. 54: 235-40.

_-_. 1906. "Pragmatism and Pseudo-Pragmatism.” Mind 15, no. 59: 375-90.

___. 1915. "Realism, Pragmatism, and William James." Mind 24, no. 96: 516-24. Seigfried, Charlene Haddock. 2001. "Pragmatist Metaphysics? Why Terminology Matters." Transactions of the Charles S. Peirce Society 37, no. 1: 13-21.

_-_ . 2004. "Ghosts Walking Underground: Dewey's Vanishing Metaphysics." Transactions of the Charles S. Peirce Society 40, no. 1: 53-81.

Shook, John R. 2000. Dewey's Empirical Theory of Knowledge. Nashville: Vanderbilt University Press.

_- _. 2004. "Dewey's Empirical Naturalism and Pragmatic Metaphysics." Transactions of the Charles S. Peirce Society 40, no. 4: 731-42.

Shusterman, Richard. 1994. "Pragmatism and Liberalism between Dewey and Rorty." Political Theory 22, no. 3: 391-413.

Slater, Michael R. 2007. "Ethical Naturalism and Religious Belief in 'The Moral Philosopher and the Moral Life." William James Studies 2, no. 1. http:// williamjamesstudies.org/2.1/slater.html 
-__. 2007. "Metaphysical Intimacy and the Moral Life: The Ethical Project of The Varieties of Religious Experience." Transactions of the Charles S. Peirce Society 43, no. 1: 116-53.

Sleeper, R. W. 1960. "Dewey's Metaphysical Perspective: A Note on White, Geiger, and the Problem of Obligation.” The Journal of Philosophy 57, no. 3: 100-15.

-_- 2001. The Necessity of Pragmatism: John Dewey's Conception of Philosophy. 1986. Chicago: University of Chicago Press.

Spiegelberg, Herbert. 1951. "Supernaturalism or Naturalism: A Study in Meaning and Verifiability." Philosophy of Science 18, no. 4: 339-68.

Suits, Bernard. 1961. "Naturalism: Half-Hearted or Broken-Backed?” The Journal of Philosophy 58, no. 7: 169-79.

Uhrmacher, P. Bruce. 2009. “Toward a Theory of Aesthetic Learning Experiences." Curriculum Inquiry 39, no. 5: 613-36.

Westbrook, Robert B. 1991. John Dewey and American Democracy. Ithaca: Cornell University Press.

Wilson, P. Eddy. 1995. "Emerson and Dewey on Natural Piety." The Journal of Religion 75, no. 3: 329-46.

Randy L. Friedman is Assistant Professor of Philosophy and Judaic Studies at Binghamton University (SUNY).

E-mail: friedman@binghamton.edu 